\title{
Australian Postgraduate Financing Options
}

\section{Bruce Chapman and Tony Salvage}

$\mathrm{S}$ ince 1991 Australian universities have charged fees, paid in advance (upfront), for a proportion of students undertaking postgraduate courses. In this paper it is argued that this is poor public policy, for both economic and social reasons. The conceptual basis for this case is explained fully.

Given the strength of argument, it is difficult to understand why different Commonwealth governments have allowed and encouraged the expansion of postgraduate up-front fees in this period. The policy situation is particularly hard to justify since a much more equitable and efficient charging arrangement, the Higher Education Contribution Scheme (HECS), has been in place for undergraduates since 1989.

The important point for policy is that HECS collects student charges contingent on incomes, and thus requires no payment at the point of entry. It is argued that a collection system of this type is a more correct policy for postgraduate education, and it is shown that such a reform can be implemented without administrative difficulties.

In January 2001 the Federal Government announced intentions to change post-graduate fee arrangements consistent with the reform promoted in this paper. The proposal is known as the Postgraduate Education Loan Scheme (PELS), and its basis and implications are considered in what follows. It is argued that while PELS is a major advance over current arrangements its institution will have important and arguably undesirable consequences with respect to the level of student charges and, more importantly, concerning taxpayer subsidies of postgraduate education. If and when these effects come to pass, the government will face the need to change the scheme. An economically and administratively viable reform to PELS is explained and justified.

\section{A Brief History of Higher Education and Post Graduate Financing}

In 1974 the Federal Labor Government abolished tuition fees for higher education and soon after took over the responsibility of university funding from the States. By 1978 the Tertiary Education Commission (TEC), a statutory body, was the sole administrator of higher education funding, including all postgraduate courses (DEET, 1993). Over the next decade or so there were no significant changes in the nature of university funding — so-called 'free' higher education was apparently accepted by both the TEC and the government as the correct approach.

Bruce Chapman is Director of, and Tony Savage is a consultant to, the Centre for Economic Policy Research at The Australian National University. 
This policy stance changed significantly in 1986 with the institution of the Higher Education Administration Charge (HEAC), a small up-front charge on all university students of $\$ 250$ that did not vary with respect to course load. HEAC is important in an understanding of the policy dynamics in two respects.

First, its institution signalled a change in the nature of political influence with respect to higher education financing since it was a Cabinet, not a TEC, initiative. In this respect it represented the beginning of a transfer to the government of decision-making power with respect to higher education financing. Second, HEAC represented government endorsement of student fees, and thus set the scene for more radical reforms involving user-pays.

While HEAC was symbolically critical, the revenue raised was trivial in comparison to the total costs of higher education (unlikely to have exceeded three per cent of teaching costs). Thus in 1987 it remained the case that taxpayers provided practically all of the finances for higher education, including postgraduate courses. At this time the conjunction of several forces made it close to inevitable that the government would move the financing arrangements towards increased contributions from students, and these were as follows.

First, the rapid increase in year 12 retention rates over the 1980 s was not accompanied by a commensurate expansion in higher education places. This resulted in large and growing queues of qualified prospective students. Second, while this problem could have been solved with increased Commonwealth budget outlays, the Labor Government was intent on fiscal parsimony and not prepared to spend the required additional taxpayer resources (see Chapman, 2001; and Edwards, 2001). Finally, and perhaps most importantly, at least two Cabinet Ministers, John Dawkins and Peter Walsh, were strongly in favour of student fees on the basis that a no-charge higher education system constituted a regressive distribution, from all taxpayers to university graduates, the majority of whom came from relatively privileged backgrounds.

In late 1987 the Minister, John Dawkins, set up a committee (chaired by former NSW Premier, Neville Wran), to examine options for university funding including student contributions. It was clear from the Terms of Reference that the government's intent was to set the scene for the introduction of fees, including for postgraduates.

The Wran committee duly delivered, albeit in a radical way. It recommended that all undergraduates be required to pay a charge, with the timing and level of the obligation being dependent on students' income. At the time the income contingent feature of the Higher Education Contribution Scheme (HECS) was unique internationally.

With the introduction of HECS it was opportune for the government to initiate financing reform in the postgraduate area, and this took the following form. In 1989 universities were permitted to charge fees for a limited range of postgraduate courses, including for employed Australian students enrolled in skillrelated courses. This policy change was justified through reference to: the benefits of revenue increases for higher education institutions; and the presumed 
advantages of institutions being able to develop specialist postgraduate courses to satisfy growing industry demand.

In 1994 the government removed all restrictions on universities with respect to postgraduate fees. This situation remained unchanged to 2001 .

As illustrated in Table 1, this policy history resulted in an extraordinary growth in the number of postgraduate students paying up-front fees in the 1989-2000 period. Specifically, there has been more than a ten-fold increase over these eleven years, with the number of postgraduate Australian students paying up-front fees in 2001 implying an average increase since 1989 of more than 20 per cent per annum.

Table 1: Fee-Paying Postgraduate Australia Students: 1989-2000

\begin{tabular}{ccc}
\hline Year & ${\text { Student Load }\left(\text { EFTSU) }^{a}\right.}^{a}$ & Annual Increase (\%) $^{\circ}$ \\
\hline 1989 & 2,351 & \\
1990 & 5,374 & 128.6 \\
1991 & 4,763 & -11.4 \\
1992 & 6,113 & 28.3 \\
1993 & 7,500 & 22.7 \\
1994 & 9,562 & 27.5 \\
1995 & 11,761 & 23.0 \\
1996 & 13,514 & 14.9 \\
1997 & 16,327 & 20.8 \\
1998 & 20,457 & 25.3 \\
1999 & 24,097 & 17.8 \\
2000 & 24,977 & 3.7 \\
\hline
\end{tabular}

Note a: Effective Full-time Student Units

Source: Unpublished data supplied by DETYA, 2001.

These changes in Australian postgraduate financing arrangements were investigated by a review commissioned by the Labor Government in 1995 (the Review of the Committee to Review Fee-Paying Arrangements for Postgraduate Courses chaired by Gordon Stanley). The review acknowledged up-front fees might not be the best approach, but did not recommended changes to the arrangements. Its support of the status quo relied on the argument that there was insufficient evidence of up-front fees adversely affecting access to postgraduate study by the disadvantaged. The view was not supported in an empirically 
convincing way. The Committee noted that up-front fee coverage of the postgraduate sector was small in the early 1990s. Importantly, it argued that in the event of postgraduate fees becoming widespread the government should consider the adoption of a HECS-type loan policy in this area. Even so, the key proposition of the Committee was that while a HECS-type arrangement might be preferable eventually, up-front fees were not widespread enough to warrant reform.

The number of students paying postgraduate up-front fees grew considerably in the late-1990s. Notwithstanding this, both Labor and Coalition governments ignored the critical suggestion of the Stanley Review of the possible move towards a HECS-style loan for postgraduate students. This changed in early 2001 with the government recommending the adoption of an income contingent loan arrangement for postgraduates. The policy is considered in detail below.

\section{Postgraduate Financing Options: Conceptual Issues}

The framework underlying the analysis presented in this section is that of the economics of education, and is based on human capital theory. This approach considers education as a process of investment, and thus involves costs and benefits for both students and taxpayers.

There are alternative ways of analysing government approaches to university funding and, as Pincus (2000) argues, to be made operational the human capital framework implicitly makes quite restrictive assumptions. As well, he stresses correctly that there are important measurement issues in interpreting rates of return to human capital as a basis for policy direction. Nevertheless, the framework is less contentious when the key policy issues concern changes in relationships, and this is the orientation of much of the empirical analysis following.

The human capital orientation leads to the promotion of three principles underlying postgraduate student charges. They are that: students should pay for some part of the costs of their education; the government should subsidise some part of the direct costs; and, charges should be collected through the tax system, contingent on a postgraduate's income. These principles are now explained.

\section{Students should pay part of the costs of postgraduate courses}

The argument that students should pay for some part of the costs of postgraduate education rests on a simple proposition. It is that individual students gain private benefits from the process. These benefits take many forms, with the most obvious economic dimension being lifetime incomes. Data are available on this issue.

The questions are, do individuals with postgraduate qualifications have high earnings compared to individuals with lower levels of educational qualifications and, if so, what is the size of this advantage? These issues are now addressed using the 1994/95 ABS Income and Housing Survey. The survey has information on the labour market experience of the members of around 30,000 households, with data for full-time workers on earnings (from the main job) cross-categorised 
by age, sex and educational attainment. This allows an exploration of the possible earnings advantages associated with educational qualifications.

It is useful to define some hypothetical scenarios to illustrate the relationships between formal skills and earnings. This was done by exploring the earnings consequences for both males and females for three education levels, namely: leaving education at age 18, and taking a full-time job until age 55; undertaking a 4 year Bachelor's degree, and taking a full-time job at age 22 until age 55; and, undertaking a 4 year Bachelor's degree followed by a 2 year postgraduate course, and taking a full-time job at age 24 until age 55 .

The data were adjusted to be in year 2000 prices and the (smoothed) ${ }^{1}$ annual earnings profiles for these hypothetical scenarios are presented in Figures 1 and 2, for men and women respectively, and by educational level. These profiles can be used to estimate (hypothetical, and average) lifetime earnings advantages of postgraduates, relative to the earnings of those with Bachelor's degrees and those without post-school qualifications. The (before-tax) results are shown in Table 2.

Figure 1: Age Earnings Profiles, Males

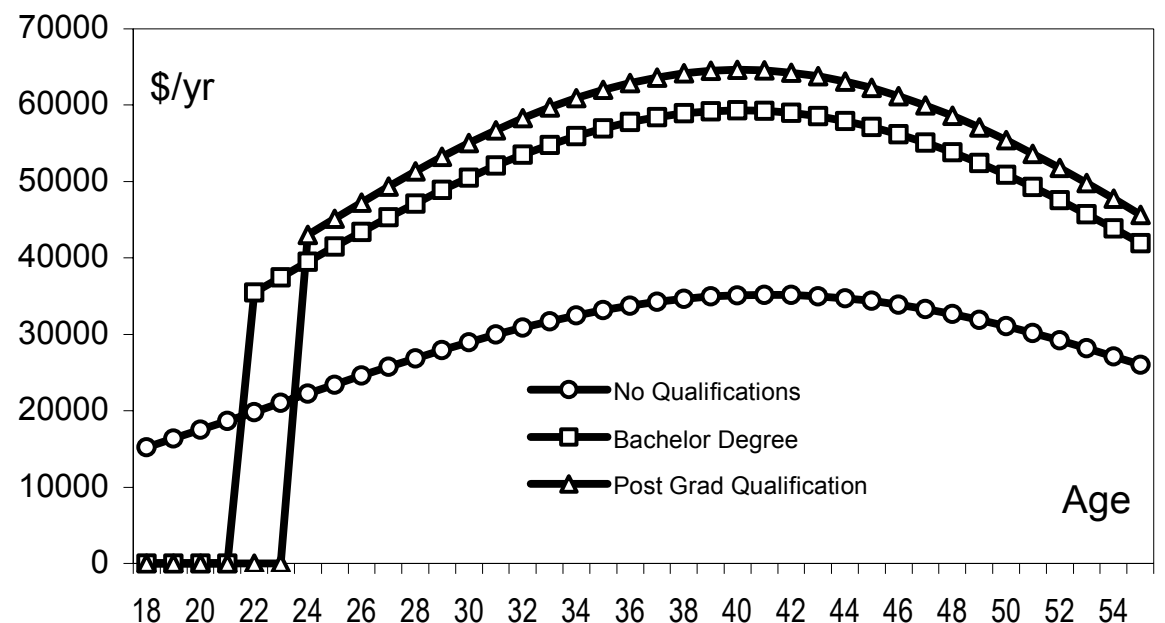

1 A conventional simple earnings function approach was used to smooth the data. The estimations have satisfactory econometric characteristics. The results are available from the authors. 
Figure 2: Age Earnings Profiles, Females

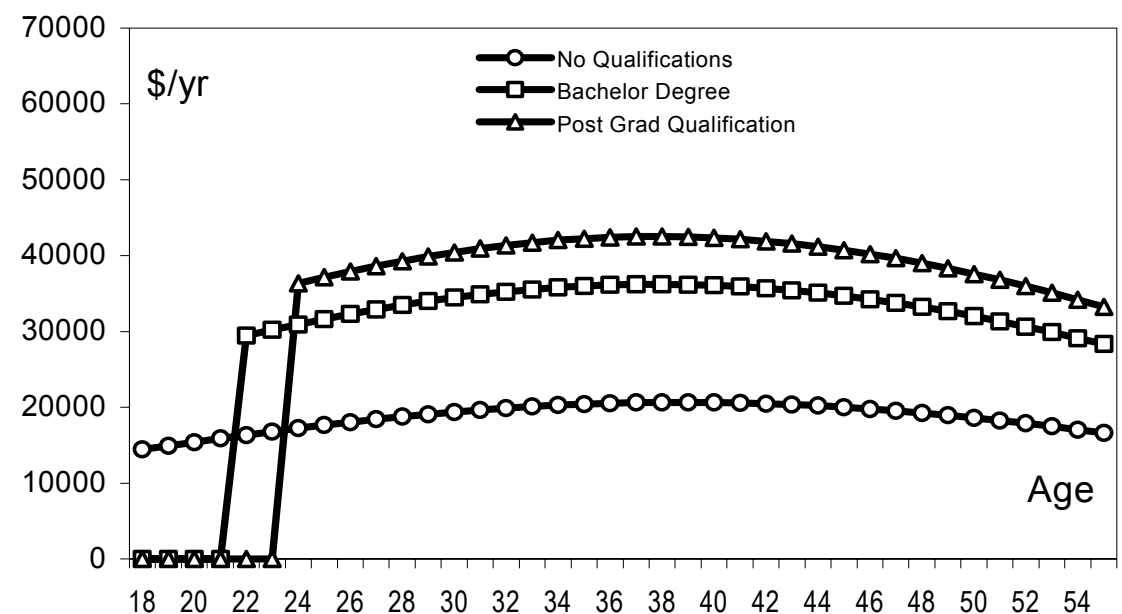

Table 2: Lifetime Earnings (Before Tax) by Educational Qualification

\begin{tabular}{lcc}
\hline Education Level: & Males & Females \\
\hline No Qualifications & $\$ 1,122,229$ & $\$ 727,461$ \\
Bachelor Degree & $\$ 1,744,718$ & $\$ 1,139,876$ \\
Postgraduate & $\$ 1,820,745$ & $\$ 1,267,904$ \\
Postgraduate/No Qualifications & 162.2 per cent & 174.3 per cent \\
Postgraduate/ Bachelor Degree & 104.4 per cent & 111.2 per cent \\
\hline
\end{tabular}

The obvious conclusion from Figures 1 and 2 and Table 2 is that, on average, there are clear lifetime earnings advantages associated with postgraduate study. The size of the benefits estimated from these data is as follows.

On average over their lifetimes, men and women with postgraduate qualifications earn around 60-70 per cent more than individuals with no qualifications, and 4-11 per cent more than those with Bachelor's degrees. More sophisticated methods used to illustrate these relativities reinforce the broad findings. ${ }^{2}$ The results of the above exercise imply that there are private economic

2 These methods include calculation of so-called 'rates of return to education' - the extent to which postgraduate investments in education benefit individuals over their lifetimes taking account of income foregone through the additional study. These 
benefits from postgraduate study in Australia, at least for the 1990s. From the perspective of the economics of education, this justifies there being a student charge, for several reasons. The most obvious of these relates to equity with respect to taxation and public expenditure, and is as follows.

The equity justification for charging for postgraduate courses can be explained through consideration of the implications of having no postgraduate course charges for students. If the government does not require contributions from the individuals benefiting from postgraduate education, it follows that those who receive it are being subsidised by all taxpayers with an important part of this subsidy very likely contributing to high private postgraduate benefits.

That this is inequitable is clear. Nick Barr (2001) makes this point best with respect to the UK by asking rhetorically a question of the form: "why should unskilled labourers and truck drivers be asked to underwrite all the costs of services which directly benefit the privileged?'

\section{Taxpayers should contribute to costs of postgraduate courses}

A second financing principle is that there should be a public subsidy for postgraduate education. This implies that postgraduates should not pay the full costs of their courses. The issue is pertinent for current Australian debate, since, if true, it promotes a case against allowing universities to charge full fees. The basis for a taxpayer subsidy is now explained.

The most important generic point concerning government subsidies is as follows. If a society derives benefits in addition to those accruing directly to the individuals participating in an activity, that activity should be subsidised to ensure it is sufficiently provided from a societal perspective. These 'externalities' or social 'spillovers' from higher education are usually thought to take the forms of:

- more informed public debate and voting behaviour, and more tolerance;

- the benefits accruing to workers and others from the imitation of the skills of the highly educated;

- $\quad$ higher tax revenue resulting from the higher productivity and wages of the more highly educated; and

- higher economic growth resulting from higher levels of education

A case for subsidising postgraduate study should include the societal benefits from research, given the critical importance played in postgraduate training of the exploration and analysis of new ideas. That is, research spillovers for the public good are likely to be a critical part of the case for subsidising postgraduate

calculations indicate there is about a nine per cent per annum return to postgraduate education compared to not having any post-school qualification, and about a 2-5 per cent return to postgraduate education compared to having a Bachelor's degree. 
education. The main reason is that research leads to higher productivity, which then contributes to economic growth and thus increases in per capita incomes.

The supposed link between postgraduate education levels and economic growth is probably strongest with respect to technological change, the engine of economic progress. Economists need to know much more about the determinants of technological change, but there is an emerging consensus that the speed of countries' adoption of innovation is enhanced when there are very high education levels in the population (Bartel and Lichtenberg, 1987). This helps make the case for a public subsidy for postgraduate education: if technological progress is determined in part by the number of postgraduates in the workforce, and this results in higher levels of economic growth, taxpayer subsidies are warranted.

A final issue relates to the fact that postgraduate students often undertake academic careers and, in this capacity, might provide spillovers as a result of their contributions to community information and policy debate. This might take the forms of media commentary and debate, and by way of informing journalists, politicians and others of significant research findings.

The bottom line is that there seems to be a strong case for some taxpayer subsidy of postgraduate education, although it is a matter of conjecture and subjectivity as to what the correct level of this subsidy should be. And there is no doubt that the appropriate subsidy is highly contingent on the nature of the postgraduate study and the subsequent occupation. While these are important qualifications, they do not undermine the case for some overall taxpayer contribution. The implication is that the costs of postgraduate study should not be financed entirely by students.

\section{Income contingent repayment}

The financing policy points from the above discussion are that both students and government should jointly contribute to the costs of postgraduate courses. While this is arguably a useful contribution to debate, the major financing policy issue with respect to postgraduate charges is not about the right level of student charges. Rather, the critical issue concerns the financing mechanism - specifically, how the charge should be collected.

The reason this warrants serious attention is that over the decade or so in which Australian universities have had up-front charges for postgraduate education, all governments have endorsed the wrong financing approach. This mistake has arguably had deleterious consequences for both aggregate Australian economic performance and lifetime income inequality, although neither assertion is ever likely to be established in an empirically compelling way.

There are myriad ways of financing postgraduate education, and the advantages and disadvantages of the major forms are considered in Chapman (1997). In what follows two approaches are compared, chosen because the first is what has taken place in Australia (up-front fees) and the second is what should have taken place (income contingent payment). 
As described above, Australian universities are allowed to charge students for postgraduate courses, and the practice is now commonplace. For courses involving fees, Commonwealth governments have provided no financing assistance. This non-involvement of the public sector is markedly at odds with basic economic theory.

The major economic problem associated with charging up-front fees for higher education is that those who can't afford to pay are unable to access loans to cover the cost. The basic concern for a bank lending for human capital investments is that, unlike many other investments, there is no saleable collateral in the event of default, such as would be the case for the housing capital market. This arises in part because slavery is against the law, and banks are thus unable to possess and sell the human capital development undertaken.

The above issues have the following important implication: up-front fees with no government financing assistance mean that many prospective students without financial resources will be excluded. There are two consequences for policy.

The first is that up-front fees erect significant barriers to the participation of the disadvantaged in undergraduate and postgraduate education. Whether or not this matters depends in part on a normative judgement of what constitutes a just society. Those valuing equality of educational opportunity will necessarily be very uncomfortable with the regressive implications of up-front fees.

Second, up-front fees mean that many educationally able and motivated people are unable to best develop and fulfil their labour market potential. This leads to a waste of talent and thus societal loss. In the economics of education framework, this social cost is the forgone delivery of maximum spillovers.

The capital market problem for educational investments is well recognised, and many different public sector policy approaches to the issue currently operate internationally. Among others are: means-tested scholarships; government subsidised bank loans; and income contingent charges. A brief consideration of the relative merits of alternative policies now follows.

A common approach involves up-front fees with fee exemptions. In this approach, fee exemption eligibility is determined by a means test applying to family income. There are important inadequacies associated with means-testing. The critical problem is that means-tested scholarships have the potential to deny access for prospective students who are not eligible and in families not prepared to pay the up-front fees. As well, these schemes are potentially regressive in that many students with scholarships will have considerable lifetime earnings benefits from postgraduate education and this benefit has been paid by all taxpayers.

Perhaps the most common higher education financing arrangement internationally involves Government subsidised bank loans. This approach has the following problems.

First, there are significant default costs, because collection mechanisms are difficult to enforce. Second, similar to scholarship arrangements, loan eligibility is usually means-tested. Thus, there is the potential of access being denied for prospective students not eligible and in families not prepared to help. Third, some prospective students will be unwilling to take bank loans as there is considerable 
uncertainty associated with graduates' capacity to meet future debt obligations after all, returns to human capital investments have a large variance.

The final financing policy approach is income contingent repayment, such as operates with HECS. This is unquestionably the best payment method - so long as it is designed sensibly - because it avoids all the problems associated with the above alternatives. The specifics are now documented.

First, since an income contingent scheme applies to all students, means-tested eligibility on the basis of family income is unnecessary. Consequently, there is no inter-family sharing issue. Thus prospective students ineligible for the meanstested fee exemptions or means-tested access to bank finances will have no access barriers with a universal income contingent arrangement.

Second, with income contingent repayments there should be no concern for prospective students with respect to their capacity to repay the loan. That is, income contingent approaches to debt repayment offer the significant advantage of there being no repayment obligations in periods in which graduates experience adverse economic circumstances. This benefit of income contingent repayment is likely to be of particular importance for higher education investment decisions since there is considerable uncertainty with respect to graduates' future incomes.

Third, so long as the collection mechanism is efficient, the administrative costs are low. With respect to HECS, for example, the use of the Australian Taxation Office to collect the debt costs less than $\$ 12$ million per annum, which is currently less than 1 per cent of the revenue collected. In comparison, some bank loan schemes operating internationally are able to deliver less than half of the total outstanding revenues.

It should be recognised, however, that there are several implications of HECS which some commentators find disturbing (Harrison, 1997). Three points are worth noting, and are as follows:

- An implication of the scheme is that not all of the debt will be recovered. The contributing reasons are that: for students choosing to repay later, once the debt is incurred there is no real rate of interest, and this suggest the potential for a high level of subsidy in net present value terms (Harrison, 1997); and there will be a small amount of default due to some graduates emigrating or dying before the debt is repaid.

- HECS does not provide price signals because institutions are required to charge set amounts varying only by course. This suggests that there are no market mechanisms inherent in the system, and thus no obvious potential for the scheme to influence resource allocation.

- Because the debt owed in any given time period is collected only after a former student's income exceeds an initial threshold, at this threshold (currently around $\$ 23,000$ per annum) the effective marginal tax rate is extremely high. This might result in perverse labour supply behaviour, although it is unlikely that this will be very important (Chapman, 1997). 


\section{Observation}

The bottom line is that the up-front fees arrangement for Australian postgraduate students has been poor policy, in both economic and social terms. It is remarkable that successive Commonwealth governments over the last decade or so have supported and promoted such an undesirable situation when income contingent collection - the more correct approach — sits comfortably and highly visibly in the form of HECS. While HECS has some limitations (particularly its lack of resource allocation implications) it still provides the appropriate charge mechanism for university funding generally. A belief in the value of research for policy should mean that argument and evidence would lead to reform, and in 2001, this happened with the government's PELS policy.

\section{PELS: A Reform in Need of Change}

In January 2001 the government announced, as part of its Innovation Statement, that an income contingent loan would soon be available to all fee-paying nonresearch postgraduate students to cover current up-front charges. The Minister, David Kemp, subsequently provided details of the scheme (The Australian, 2001).

The scheme will operate in a similar manner to HECS, with one main exception. This is that HECS charges are set by the Commonwealth and are invariant between universities, but with PELS individual institutions set the tuition fee for all postgraduate courses. Eligible students will be able to borrow enough to pay any tuition fee set, and will repay the loan according to HECS parameters.

As stressed earlier in the conceptual discussion, there are powerful reasons for replacing postgraduate up-front fees with an income contingent charge mechanism. Allowing the payment of up-front fees with the use of HECS-style loans will increase the access of the relatively disadvantaged to postgraduate studies. This will have the two important effects of increasing the pool of talent available for postgraduate studies and expanding the access of the system to the less privileged.

Because income contingent payment is far preferable to up-front fees, this policy change should be applauded. Moves away from up-front fees and towards income contingent repayment reflect correct principles of reform for the Australian higher education system. There are some complicated issues with respect to the form of this particular proposal, however, and they might well mean that PELS will need to be changed soon after its institution.

Some implications of PELS for postgraduate charge levels

The Minister has argued that competition would restrict the extent to which universities would commensurately increase postgraduate fees, saying: 'We're not expecting that there will be any significant change in fees as a result...'. However, this is more complicated than is apparent. In analysing the implications of this change it is critical to recognise that a postgraduate charge paid with an 
interest-free loan is necessarily different to the fee received by the university. This is because the university receives the money at the time of enrolment, but the student repays the debt later. Critically, the absence of a real rate of interest on the debt means the student will necessarily be facing a lower financial impost than the actual charge. In other words, there will be a government-financed subsidy.

The extent of the subsidy depends on the length of time before the student begins to repay the postgraduate loan, and the time taken to repay it once repayments begin. That is, among other things, the subsidy depends on students' expected future incomes and the level of unpaid HECS undergraduate debt at the time the postgraduate loan is taken. The latter point is critical because the postgraduate obligation will only start to be repaid once other HECS obligations have been met. This means that those students starting a postgraduate qualification when they have a large undergraduate HECS debt will have a long period of subsidised benefit, and thus will implicitly face a relatively small charge in true financial terms. On the other hand, postgraduate students with no HECS debts already earning income above the first repayment threshold will receive relatively small subsidies.

Unambiguously, however, if the nominal size of the charge remains unchanged, the new scheme financially benefits all students taking the loan. This has a very important implication for a university's postgraduate pricing policy in the context of the government allowing complete postgraduate fee flexibility. This is that, because these new arrangements mean that the effective charges faced by students are now lower than before, universities will be able to increase the fee. Importantly, these fee increases, while real for the university, are not necessarily true financial increases for students since they can now defer the payment and consequently benefit financially from the interest rate subsidy implicit in HECS, and PELS.

The existence of competition between the universities will have limited impact on the above. After all, all universities will have the benefit of students now facing lower true charges. The obvious prediction then is that postgraduate charges, in nominal terms, will increase. These higher entry charges mean that universities will be unambiguously better off, since they will be receiving the additional revenue at the time of student enrolment. The financial implications for prospective postgraduate students are ambiguous, since the benefits of having an interest rate subsidy will be offset by the nominal charge increase.

A critical policy issue is that the costs of the subsidy will be financed by the public sector. This is because the government will be providing loans when students enrol, but recovering only the same nominal repayment later. That is, the interest rate subsidy from the new scheme comes from taxpayers, implying that PELS has a regressive potential. ${ }^{3}$

\footnotetext{
${ }^{3}$ This is a complicated issue. PELS will only be regressive unambiguously, compared to current arrangements, if postgraduates pay less than before in true financial terms, and if they earn more than average taxpayers.
} 


\section{Estimates of taxpayer subsidies}

An obvious way to work out the size of the subsidies to students (and universities) implicit in PELS is to compare the up-front charge with calculations of the "net present value' of the debt repayment. The net present value calculation takes into account the financial benefit to the student of not having to pay a real rate of interest on the debt. It is thus lower the longer it takes to repay the debt, since the student has the gift of the rate of interest subsidy for every year that the debt is outstanding.

There are an infinite number of possible illustrations of the size of the subsidy from PELS, and for simplicity in what follows we report just a few. The calculations use the 1994/95 ABS Income Distribution Survey, employed previously, to illustrate the relative income advantages of postgraduate education.

The first scenario is as follows. Imagine a person has completed a four-year undergraduate degree begun at age 18 and completed at age 22 and has already incurred a middle-range HECS debt of $\$ 19,720$. It is assumed that the PELS debt is $\$ 19,750$ per year for a two-year postgraduate course (that is, the current charge for an MBA at the University of Melbourne). In this case students will have the benefit of not paying any real interest on the additional debt until their existing HECS debt is repaid. In this scenario the up-front fee is $\$ 39,500$ and the net present value of the charge is $\$ 19,507$ for men and $\$ 16,022$ for women. That is, the subsidy is around 50 and 60 per cent for men and women respectively.

The second hypothetical scenario involves 32-year old student undertaking a two-year postgraduate course with an annual up-front fee of $\$ 8,000$ who have already paid their HECS debt. In net present value terms the up-front fee is $\$ 15,849$ and the net present value of the PELS debt is around $\$ 13,000$ for both men and women. That is, the subsidy is of the order of 9 per cent.

\section{Policy responses as a result of the subsidy}

In response to this budgetary issue the government has several options. One possibility, already raised publicly, is that increases in nominal postgraduate charges could result in the government capping the total amount of a student's HECS plus PELS debt. This would be an undesirable policy response, for the following reason.

Putting a limit on student debt in a context in which universities are able to set postgraduate charges is very likely to mean that many postgraduates will then face charge obligations exceeding the level of income contingent loans available to cover charges. This would result in students having to pay top-up fees to be paid with no access to income contingent loans. The social and economic arguments against any forms of up-front fees, as explained previously, then apply. This would be a very poor policy outcome.

Second, the government could cap postgraduate charge levels while allowing unrestricted access to HECS-style loans. Such a policy response would essentially be an extension of the differential form of HECS introduced in 1997. This has the 
significant advantage of ensuring an income contingent method of payment for all postgraduate student charges, and is thus far preferable to the first option.

However, neither of the above policy responses address the subsidies implicit in PELS. A third option achieves this, and could work as follows.

This policy would allow universities to set the postgraduate fee, perhaps with a maximum level for courses determined by the government, with students having access to a HECS-style loan covering all charges. However, those students choosing the loan option would commit to repaying an extra 25 per cent of the charge in nominal terms. There are several advantages of this approach, now explained.

The first is that the additional impost on students significantly decreases the subsidy implicit in PELS. That is, with this option the government would eventually recover loan repayments higher in nominal terms than the finance provided to students at the time of the charge.

The major benefit of the approach is that in net present value terms students taking the pay later option would be paying approximately the same as students paying up-front. With this innovation the new PELS scheme would not be introducing an additional subsidy for postgraduate studies.

The second benefit of this option concerns administrative simplicity. That is, it would mean the institutionalisation of a financing reform for postgraduate financing which is entirely consistent with the current HECS arrangements for undergraduate education. That is, undergraduate HECS offers a 25 per cent discount for an up-front payment, and this is equivalent to there being a 25 per cent higher nominal payment for students taking the pay-later option. Policy consistency between undergraduate and postgraduate financing arrangements would be the desirable result.

\section{Observation}

The Government's suggestion to make available income-contingent loans to assist postgraduates to pay fees is a productive development in Australian higher education financing policy. As a result there should be decreases in the incidence of up-front fees for postgraduate study, and this means a lower wastage of educational talent, a better workforce, and improvements in opportunities for less well off prospective students.

However, because the new scheme entails the use of an interest-free loan, a sizeable proportion of students will receive a government subsidy and will increase effective demand for the service. This is likely to facilitate nominal charge increases, meaning that universities will receive higher charge revenues. The government will thus be subsidising both students and universities more than currently with no apparent justification. Moreover, a possible response to the above would be for the government to cap a student's total HECS debt. This would have the very undesirable result of moving the system to top-up fees.

A preferable response to this issue would be to offer a 25 per cent discount for those paying up-front - the way undergraduate HECS works. This limits the 
subsidy going to those who choose to pay later and would promote administrative efficiencies. Application would be straightforward: the government pays the fee to the university for the student and the student agrees to repay through the tax system a nominal sum which is 25 per cent higher.

\section{Conclusion}

In the 1989-2000 period the incidence of up-front fees for Australian postgraduate courses increased considerably. In principle the existence of a charge for the service should not be controversial if Australians with postgraduate qualifications receive important private benefits from the process.

The existence, and even the growth, of these charges is not a major higher education policy problem. However, the critical issue for policy relates to the financing arrangements associated with postgraduate charges. The paper explains that the lack of government financing assistance for Australian postgraduate students over the last decade or so has probably meant that prospective talented students have not been able to access the system. There are associated social and economic costs.

It is argued that government financing assistance with respect to postgraduate charges is necessary, with the best approach being an income contingent charge system, such as HECS. This has recently been recognised by the government with the suggestion of PELS, which allows students access to HECS-style loans to pay postgraduate fees. This is an important and productive reform.

However, the paper argues that the PELS arrangements will result in higher nominal charges for students and, more importantly, significant potential increases in taxpayer subsidies to universities. It is likely that when this is understood the government will seek to change the scheme. There are several options, and it is explained that a preferred solution would be to have a 25 per cent discount for the up-front payment of postgraduate charges.

\section{References}

Bartel, A. and F. Lichtenberg (1987), 'The Comparative Advantage of Educated Workers in Implementing New Technology', Review of Economics and Statistics 69(February):111 .

Barr, N. (2001), The Welfare State as Piggy Bank, Oxford University Press, Oxford.

Chapman, B. (1997), 'Conceptual Issues and the Australian Experience with Income Contingent Charges for Higher Education', The Economic Journal 107(442):738-751.

Chapman, B. (2001), 'The Capacity of Public Universities to Meet Australia's Higher Education Needs', Submission to the Senate Employment, Workplace Relations, Small Business and Education References Committee Inquiry, Canberra.

Department of Employment, Education and Training (1993), National Report on Australia's Higher Education Sector, Canberra. 
Edwards, M. (with C. Howard and R. Miller) (2001), Social Policy, Public Policy: From Problem to Practice, Allen \& Unwin, Sydney.

Harrison, M. (1997), 'The Funding of Teaching Services in Higher Education', Appendix 15 in Department of Employment, Education, Training and Youth Affairs, Learning for Life: A Policy Discussion Paper, Canberra.

Higher Education Council (various years), Annual Reports, AGPS, Canberra.

Pincus, J. (2000), 'Do we Know Federal Treasury Overspends on Undergraduates?', Agenda 7(3):277-288.

The Australian (2001), 'Interview with David Kemp', 6 February.

The authors acknowledge constructive critical comments from two anonymous referees. Errors are the responsibility of the authors. 